DOI: 10.5824/1309-1581.2018.1.006.x

http://www.ajit-e.org/?menu=pages\&p=details_of_article\&id=313

\author{
Received :06.02.2018 \\ Editorial Process Begin: 08.02.2018 \\ Published: 12.02 .2018
}

\title{
Ölümsüzlük ve Yapay Zekâ Bağlamında Trans-hümanizm
}

\author{
Aysel DEMiR, Yrd. Doç. Dr., Kırıkkale Üniversitesi, Felsefe Bölümü, Kırıkkale-TÜRKIYE \\ ayselmus1@hotmail.com, ORCID iD: 0000-0001-7283-1565
}

Öz Bu çalışmada, trans-hümanizm hareketi temelinde ortaya çıkan ölümsüzlük, yapay zekâ bă̆lamında yeni bir varoluş aşamasına giren insanın durumu incelenip, gelecekte yeni insan varoluşunu nelerin beklediği, devlet yapısı ve siyasetin bu insan varoluşunu nasıl kullanacă̆ı hümanizm, trans-hümanizm ve post human (insan sonrası) varlık temelinde incelenmiştir. Iç̧inde bulunduğumuz yüzyıl insana, insanlığa çok büyük gelecekler vaat etmektedir. Bu vaatler, ileri teknolojinin etkisiyle insan aklının sınırlarını aşan, hatta insan aklını teknoloji aracılığıyla kontrol altına alan gelişmeler olarak karşımıza çıkmaktadır. Hümanizm, insanın değerini kabul eden ve insanı insan olma bakımından konu eden bir felsefe olup, onun bir sonraki basamağ ileri teknolojiyi temel alan trans-hümanizmdir. Yaşamın uzatılması veya ölüme çare bulunması, yapay zekâ ile zekanın daha da geliştirilip, bir üst insana ulaşma çabasını, trans-hümanizm felsefesi ileri teknolojinin ve çağın bir gereği olarak görür. Bununla birlikte her ne kadar ileri teknolojinin getirdikleri insanlığın geleceğgi için olsa da devlet ve siyaset yapılanması içinde bu ilerlemelerin kötüye kullanılması kaçınılmazdır.

Anahtar Kelimeler: İleri teknoloji, trans-hümanizm, hümanizm, post human, ölümsüzlük, yapay zekâ, üst insan, siyaset

\section{Trans-Humanism in the Context of Immorality and Artifical Intelligence}

Abstract

In this study, it is analysed that artificial intelligence, immortality on the basis of trans-humanism and examined the situation of Human being who has a new existence stage. It is searched what human being expected in future, how the state and politics will use this new existence stage according to humanism, trans-humanism and post human. This century has a promising future to human being and humanity. This promising is appearance as developments which are transcendent, even control the human mind with the effect of advanced technology. Humanism is a philosophical stance that emphasizes the value and agency of human beings and its next stage is trans-humanism. Transhumanism philosophy takes the advanced technology as a necessity of age which in struggling to reach a upper man through the prolongation of life, the remedy for death and the artificial intelligence. However, although high tech brings new developments for the future of mankind, it is possible to use the high tech in state and politics negatively.

Key Words: Advanced technology, trans-humanism- humanism, post-human, immortality, artificial intelligence, upper human, politics.

\section{GíRIŞ}

Yirmi birinci yüzyıl insana ve insanlığın geleceğine dair farklı seçenekler sunmaktadır. Bu seçenekler, ileri teknoloji aracılığıyla zihnin sınırlarını zorlayan, hatta onu aşan ve teknoloji aracılığıyla insan aklını kontrol altına alan gelişmeler olarak karşımıza çıkmaktadır. Bilgisayar teknolojisi ve bioteknolojinin durdurulamaz yükselişi, bizi trans-hümanizm konusu ile tanıştırmaktadır. Trans-hümanizm, teknoloji çağının getirdiği yeni bir felsefi kavram ve harekettir. 
$\mathrm{Bu}$ hareketin temelinde, insandaki temel özelliklerin geliştirilmesini amaç edinen felsefi bir akım olan hümanizm bulunmaktadır. Trans-hümanizm gelecek hakkında bir düşünme yoludur (Bostrom, 2003: 4). Hümanizm, insanın değerini her şeyin temeli kabul eder ve insanın insan olma bilincini konu eden bir felsefe alanı olarak ortaya çıkar (Abbagnano, 1992: 763). Hümanizm'in bir sonraki basamağı ise trans-hümanizmdir ve bu noktada, teknolojinin insan üzerinde birebir uygulanmasıyla beraber insanoğlu, bir üst-insana dönüşme aşamasına girer. Bu anlamda, transhümanizm felsefesi teknolojinin varlığıla kendine anlam katar. Buna göre, öncelikle transhümanizm kavramının içeriğini belirlemekte fayda vardır.

Trans-hümanizm; insanın fiziksel ve bilişsel yeteneklerinin arttırılması, yaşlanma ve hastalanma gibi istenmeyen yönlerinin ortadan kaldırılması amacıyla teknoloji ve bilimden faydalanılması gerektiğini öne süren bir düşünce hareketidir (Bilgen, 2016). Trans-hümanist düşünürler ise insan geliştirme tekniklerini, yüksek teknolojiyi insanlar üzerinde kullanabilmeyi ve bu durumun olası sonuçlarını tartışmaktadırlar. Diğer bir ifadeyle, trans-hümanizm; nanoteknoloji, gen klonlama, yapay zekâ vb. gibi ileri teknolojilerin insan üzerinde detaylı bir biçimde kullanılmasını destekleyen kültürel bir hareketliliktir. Bunlar, insanların ileri teknoloji ile daha da geliştirilmesinin çağın bir gerekliliği olduğunu, hatta bir zorunluluk olduğunun kabul edilmesinin gerektiğini ileri sürerler. Trans-hümanizm fikri üç teknolojik ilerlemeyle bağlantılıdır. İlki, radikal nanoteknolojinin bir türüdür. İkincisi, yaşam süresinin uzatılması temelinde yaşlanma ve ölüme çare bulunmasıdır. Üçüncüsü ise bilgisayarın gücünün yapı değiştirmesiyle yapay zekâ ve ileri nanoteknoloji aracılığıyla üst insan seviyesine ulaşmaktır (Jones, 2016: 9). Buna göre hümanizm, insanın gereksinimleri olan toplum içindeki bireyi temel alan, her şeyi insanın hak ettiği biçimde yaşaması gerektiğini savunan düşünceyken, trans-hümanizm için sadece insanca yaşamak yetmeyip teknolojik olanaklar imkân verdiği sürece, insanın ve insanlığın daha üst düzeye çıkmasının mümkün olduğunu savunan düşüncedir.

Trans-hümanizm düşüncesini savunanların asıl amac1; fiziksel ve zihinsel olarak insanları geliştirip, bir anlamda varoluşun yaşam sınırlarını daha iyiye doğru genişletmektir. Diğer bir anlamda amaç, insan hayatı ile insan olmayı daha da iyileştirmek ve bunu da aşkın bir yolla yapmaktır. Bu durum, dolaylı yönden insanlığı mutluluğa götürür. Bununla birlikte, tarihsel sürece baktığımız zaman mutluluğa ulaşmanın Eski Yunan ve Helenistik felsefede temel amaç olduğunu görürüz. Orta çağda mutluluk, tanrıya ulaşmakla bir sayılırken, 17. ve 18. Yüzyıllarda mutluluk 'iyi olma' durumu olarak tanımlanmıştır. 19. Yüzyıl ile birlikte mutluluk, utilitarianizm temelinde bireysel mutluluğa odaklanmıştır. Örneğin Jeremy Bentham için, bizim yapmamız gereken şeyleri acı ve zevk belirler. Mutluluğa neden olan şey ise onlar arasındaki dengenin bilimsel analizidir. Bentham, düşünce ve eylemlerinde "en çok sayıda insan, en yüksek düzeyde mutluluk" ilkesiyle hareket etmektedir (Bentham, 1996: 36-7). Trans-humanist deklarasyon doğrudan doğruya mutluluk ile uğraşıp onu tartışmaz. Bununla birlikte, temel amaç yine de daha iyiye, daha mutlu eden şeylere insanı ulaştırmaktır. Trans-hümanist düşünce, 19. Yüzyıl mutluluğunun hedonist anlayışının genişletilmiş halini bize verir. Kişisel tatmine odaklandıkları için, Modernizm öncesi kabul gören mutluluk ve erdem arasındaki bağlantıyı trans-hümanistler dikkate almazlar (Hansell and Grassie, 2010: 38). Trans-humanistler; yaşamdan memnun olma, kendini tatmin etme ve kendini gerçekleştirmeden söz ederler. Mutluluğun objektif veya sübjektif yönü arasındaki ilişkinin analizini yapmak peşinde olmayıp, temel amaçları, insan yaşam süresinin en iyi biçimde uzatılması ve ölümün bir anlamda ertelenmesidir (Hansell and Grassie, 2010: 39). 
Ayrıca trans-hümanistler, ölümsüzlüğün olabilirliğini teknoloji aracılığıyla ortaya koymak istemektedirler. Her ne kadar, her birimiz yeni doğan nesillerimizle ölümsüz olmanın tadına varmak istesek de bunu gerçek anlamda gerçekleştirmemiz daima çok uzak ve hatta imkânsız görünmüştür. Bununla birlikte, 21. Yüzyılda ileri teknoloji bize neredeyse imkânsızı sunup, zihnimizde 'acaba böyle bir şey gerçekten olabilir mi veya olmakta mıdır?' sorusunu uyandırmaktadır. Elbette trans-hümanist teknolojiler bize bu durumun gerçekliğini göstermekte, yaşam ve yaşam sürelerini insanın hem lehine hem de aleyhine olarak değiştirme olanağ1 sağlamaktadır.

Trans-hümanizmde, insan zihninin ve bedeninin birtakım kodlamalarla kontrol altına alınması ve gerektiğinde en ileri teknolojiyle hazırlanmış organların asıllarıyla yer değiştirmesi düşüncesi oldukça istenilen bir durumdur. Ölümsüzlüğe ulaşma düşüncesiyle hareket eden insan, bu yolda zekâ seviyesini artırarak ve yaşam süresini beden üzerinde uyguladı̆̆ı yeni yöntemlerle uzatarak hümanizmden trans-hümanizme geçmeye, diğer bir ifadeyle, bulunduğu durumdan üst bir seviyeye ulaşmaya çalışmaktadır. Bu da tam anlamıyla dönüşümün kendisidir ve bu dönüşümde, 'teknolojik insan' hedef noktasıdır. Teknolojik insan, insan organizmasının dışında yapay olarak üretilmiş ve organizmaların yerine geçecek olan teknolojik uzantıların anlam kazandırdığı bir varliktır.

Ölümsüzlüğe ulaşma çabasında insan ömrünü uzatmak, insan zihnine yapılan teknolojik yüklemelerle çok süper zeki insanlar tasarlamak 'acaba bu durum insanlığın sorunlarını çözmede ne derece bize katkı sağlamaktadır?’ sorusunu sormaya zorlamaktadır. İnsanlığın sorunlarını çözmek için süper zeki insanlar tasarlamak bir zorunluluk mudur? Peki gen teknolojisi aracılığıla yaratılmak istenen üst insan, yaşamımızdaki problemleri gerçekten çözer mi yoksa kendisi bir problem olarak mı ortaya çıkar? Bu noktada, teknoloji ile beyinleri kontrol altına alınan insanlık için 'insanlar $\mathrm{m} ı$ robot olur yoksa robotlar $\mathrm{m} ı$ insana dönüşür?' sorusu, en can alıcı soru ve sorun olarak ortaya çıkmaktadır.

İnsanlığın iyiliğine odaklanan hümanizmden sonra trans-hümanizm, bizi üst insanın yaratılmasına götürürken, aynı zamanda bizi post human ile, diğer bir ifadeyle insan sonrası varlıkla karşı karşıya bırakmaktadır. Max More'a göre trans-hümanizm, insanın Homo Sapiens olması ve gelecekteki post human hali arasındaki yerdedir (More, December 2004). Bu anlamda trans-hümanizm, hümanizmin sonunu getiren ama post human'ı başlatan bir aracıdır. Bununla birlikte üst insan ile post-human arasında bir takım aşama ve bilinç farkları bulunmaktadır. Üst insan, insan olmayı zekanın sınırlarını aşarak çözen ama insanlıktan ve insan olmaktan duygularıyla ve yaşamıyla henüz çıkmamış kişi demektir. Ancak hem zekâ hem de yaşam bakımından bu gelişim süreci tamamlandığında ortaya çıkan 'süper yapay zeka' artık insan türünden farklı bir tür olacaktır. Post human olarak adlandırılan insan sonrası tür, artık bildiğimiz anlamdaki Homo Sapiens olmaktan çıkacaktır. Çünkü bu süreçte, Homo Sapiens'in yapı ve biçimiyle organik anlamda oynanmıştır. Buna göre de ontolojik açıdan varlığın hem yapısı hem de içeriği değişecektir. Bu, bir anlamda varlığın dönüşümü ve varlık tanımlamasının da değişimi anlamına gelmektedir. Bu durum ise insanlar üzerinde, Trans-hümanizm'in insanı insanlıtan çıkarıp, teknolojik canavarlar yarattığı düşüncesine yol açmaktadır. Oysa istenilen durum tam aksinedir. Trans-hümanizm de insanın her yönüyle iyileşmesi ve gelişmesi esastır. Amaç; uzun ömürlü, üstün zekalı ve üstün güçlere sahip süper sağlıklı insanlar yaratmaktır, insan beynini bilgisayara veya robotlara yükleyerek onları makinelerle değiştirmek değil. ${ }^{1}$

\footnotetext{
${ }^{1}$ Ancak elbette iktidarın teknolojinin aracılığıyla bu durumu kötüye kullanması beklenilebilir bir olaydır.
} 
Trans-hümanizm sadece ve sadece teknolojiyi en iyi yönde kullanmak istemektedir, asla aksi bir düşünce düşünülmemelidir. Bununla birlikte, elbette diğer her alanda olduğu gibi kötü ellere hizmet etme ihtimaline de açıktır. Özellikle gelecekte, yapay zekâ ve ölümsüzlüğü bir devlet yapılanması içinde kontrol altına alma durumu, belki de tek tür robotların ortaya çıkmasına neden olacak, devlet yönetiminde bulunan kişi bütün zekâ kontrolünü elinde bulunduracak ve ölümsüzlüğün bulunması ile de iktidar, devlet yönetiminde elinde bulundurduğu kontrolü ve gücü asla bırakmak istemeyecektir. Kendi iktidar ve çıkarına göre kendi adaletini kurma çabasına girişecektir. J. Baudrillard, Simgesel Değiş Tokuş ve Ölüm adlı eserinde bu düşünceleri destekler nitelikte şu söylemlerde bulunmuştur: “Ölüm sonrası yaşam düşüncesinin ortaya çıkışı iktidarın doğmasına yol açan asal olaydır. Çünkü bu düzenek, sadece bu dünyada zahmete katlanma zorunluluğu ve bunun karşıllı̆ında öteki dünyada ödüllendirilme gibi bir şantaja yol açmakla kalmayıp, aynı zamanda bilinç altına yerleştirilmeye çalışılan ölme yasağıyla birlikte, bir de bu ölüm yasağını denetleyen bir iktidar süreci de oluşturulmuştur"' (Baudrillard, 2011: 227).

$\mathrm{Bu}$ anlamda, insanlığın idealist eğilimleri her ne kadar daima iyiye, güzele yönelse de insanoğlunun aklının bir köşesinde daima negatif düşüncelerin ve distopyaların bulunduğu da bir gerçektir. Ancak, bu negatif bakış açısı ve ihtimaller senaryolarından dolayı; gelişimi, değişimi ve hatta dönüşümü göz ardı ederek teknolojinin getirdiklerine gözleri ve kapıları kapatmak insanlık adına yanlış bir adım olacaktır. Bu teknolojik ilerlemelerin getireceği pozitif yönler de kabul etmemiz gereken gerçekler olarak karşımıza çıkmaktadırlar. İnsanlar başlangıçta, çoğunlukla teknolojinin insan zihnine ve bedenine getirdikleri yeniliklere ve değişikliklere karşı çıkma eğilimindedirler. İnsanoğlu bir alışkanlıklar varlığıdır. Özellikle teknoloji aracılığıyla alışkanlıklarının, benliklerinin yok edildiğini düşünürler. Ancak, daima felsefi bağlamda iyiye yönelme çabası içinde olan insanoğlu, olması gereken bağlamında, teknolojiden vazgeçmeksizin de iyiye yönelerek yaşama katkı sağlayabilir. Bu anlamda genellikle bilim ve felsefe insanları, teknolojiden yararlanırken ortaya çıkan etik ve insan hakları bağlamında karşılaşılan negatif sorunlara dikkat çekerler. Elbette ileri teknolojinin getirdiği bir takım etik ve insan hakları sorunları göz ardı edilemez. Nasıl teknolojideki gelişmeler, insanoğlunu değiştirip ve dönüştürüyorsa, insan haklarında da değişen duruma ayak uydurma söz konusu olmalıdır. Örneğin, hak bağlamında ötenazi ve kürtaj olayları hala etik olarak tartışılsa da teknolojinin gelişmesiyle, sağlıklı yaşam sürecinin uzatılması temelinde özellikle "sağlıksız bir çocuğa sahip olmama hakkı" nın varlığı gündeme gelmiş ve o da ötenazi gibi bir trans-human hakkı olarak ortaya çıkmıştır. Buna göre öncelikle, hümanizm temelinde, insanın insan olması bakımından hakları vardır. Daha sonra, teknolojinin etkisiyle ve bireysel hakların genişlemesiyle bu günkü trans-human haklarına kadar gelinmiştir. Bundan sonraki süreç post-human haklarının uygulanmasına kadar gitmektedir. Post-hümanizm sürecinde, yapay zekâ ve ölümsüz insan temelinde insan haklarının yerini, basit anlamda birey hakları, geniş anlamda 'üst insan' hakları alacak gibi gözükmektedir.

İnsanoğlu tarihsel süreç boyunca, bilinçli veya bilinçsiz olarak 'üst insan' olma peşinde koşmuştur. Özellikle mitolojik hikâyelerde, tanrı ve yarı tanrılara üstün nitelikler verilerek bir anlamda en iyi olanın tanımlamaları yapılmıştır. Örneğin, Eski Yunan da Zeus, tanrıların tanrısı olarak en üstün nitelemesini kazanırken, aşk tanrısı Eros yarı tanrı yarı insan nitelemesinde yine bize üst insan örneğini vermektedir. Trans-hümanizm her ne kadar yeni bir kavram olsa da onun izleri Gılgamış Destanına kadar gitmektedir. Gılgamış Destanı, Nuh Tufanıِ'nın anlatıldığı ilk yazılı eser olup, burada ölümsüzlügü arayan bir kralın öyküsü aktarılır. Gılgamış, tanrılar gibi ölümsüz ve üstün 
olmak ister. Yarı insan yarı tanrı olan Gılgamış, karada ve denizde olan biten her şeyi bilen başarılı bir yapı ustası ve yenilmez bir savaşçıdır. Gılgamış'ın tanrısı Enlil, Gılgamış'a insan oğlunun ancak büyük bir eser bırakarak ölümsüzlüğe erişebileceğini öğütler ve bunun üzerine Gilgamış ölümsüzlüğe ulaşma serüvenlerine başlar. ${ }^{2}$ Utnapiştim ölümsüzlüğün sırrını bilen bir bilgedir. Utnapiştim'i bulan Gılgamış, onun verdiği ölümsüzlük otuyla gençliğine yeniden dönecek ve ölümsüzlüğe kavuşacaktır. Ama, Gılgamış ölümsüzlük otunu yemeye fırsat bulamadan onu bir yılana kaptırır ve böylece ölümsüzlük elinden kayıp gider. Yine bu mitolojik hikâyeye göre Tanrı, insanları engellemiş ve tek bir yerde toplanıp büyük bir medeniyet kurup kendi katına erişmeye cüret edemesinler diye dünyanın dört bir tarafına dağıtıp farklı farklı lisanlara bölmüştür (Battero, 2015: 58-.120).

Bu dünyaya fırlatılan insanoğlu ölümlü, sonlu bir varlık olması bakımından ölümsüzlüğün daima peşinde koşmuş ama ölümlülüğünü aşamayınca, üreyerek kendinden bir nesil birakmakla bu açı̆̆ kapatmaya çalışmıştır. Günümüzde teknoloji, bu istence karşılık verebilecek düzeye gelmiş, kendini aşan aşkın bir varlıkla bizi yüz yüze getirmiştir. İşte trans-hümanistler, insanoğlunun bu ihtiyaçlarının gerçekleştirilmesi için bilim ve teknolojinin kapılarının sonuna kadar açılması gerektiğini düşünürler. Trans-hümanizm'in genel düşüncesi; insanların daha sağlıklı ve uzun ömürlü bir hayat sürmesi, daha zeki ve akıllı olması için teknolojinin olanaklarından faydalanmalarıdır. Bu noktada üst insan, aşkın insan geleceğe yönelik insandır ve temelde her şey insanlık içindir.

Görüleceği üzere günümüz dünyasında, insanın ölümsüzlük arzusu ve teknolojinin gelişmesiyle yapay zekâ trans-hümanizm gibi yaklaşım tarzlarıyla boyut değiştirmiştir. Bu arayışlar, geleneksel ölümsüzlük anlayışının tasvir edildiği 'öbür dünya' düşüncesinin tersine, varlığın bu dünyada ölümsüzlük kazanması anlayışını dile getirmektedir. Bu düşünceyle, şimdiye kadar kabul gören dualist dünya görüşü yerini tekrar materyalist dünya görüşüne birakmaktadır. Transhümanistlerin üstün insanı ortaya koymalarının yolu, yapay zekâ ve sentetik biyolojiden geçmektedir. Teknoloji aracılığıyla yeni bir insan tasarımı ortaya konmakta, insanlık kendini farklı yapısal özelliklerde tanımlamaya başlamaktadır ve böylece, varlığın özü ontolojik anlamda değişmektedir.

$\mathrm{Bu}$ anlamda da insan bedenini değiştirme düşüncesi kutsal bir tabu olmaktan çıkmakta, insan da kendi istencine göre kendisinin yaratıcısı olmaya başlamaktadır. Özellikle sentetik biyoloji ile aşkın üst insan gücü eline almaya başlayacaktır. Bu noktada, üst insan hem yaratıcı hem yok edici özellik kazanarak kontrolü eline alan önemli bir 'güç' haline gelmektedir.

\section{Ölümü Yenmek}

Yaşanılan süreçte, henüz ölümü yenme aşamasında değiliz ancak teknoloji ile yaşamı daha katlanılabilir haline getirerek, ömrü uzatma gücünden de yoksun değiliz. Belirtildiği üzere, insanoğlunun üstün insan olma ve ölümü yenme düşünceleri potansiyel olarak daima var olmuştur ancak bu düşüncelerin aktüel hale gelecek aşamaya ulaşması, insanı beklenmedik çatışmalarla da baş başa bırakacaktır. Artık vücudun mekanik bir yapıyla etkileşime geçip

\footnotetext{
${ }^{2}$ İlk serüven Gılgamış ile Gök tanrısı Anu arasında geçer. Halkına acımasız davrandığı için Gılgamış’a öfkelenen Anu, onu öldürmek için vahşi bir hayvan olan Enkidu’yu üzerine salar. Enkidu ile Gılgamış arasındaki savaşta Gılgamış üstün gelir. Daha sonra Enkidu Gılgamış’ın en yakın dostu ve yardımcısı olur. Bunun ardından gelen serüven Gılgamış ile aşk tanrıçası İştar arasında yaşanır. İştar Gılgamış’a evlenme önerisinde bulunur. Gılgamış bunu reddeder. Onuru kırılan İştar Gılgamış’ı öldürmek için yeryüzüne bir boğa gönderir. Gılgamış, Enkidu'nun da yardımıyla boğayı öldürür. Enkidu rüyasında, boğayı öldürdüğü için tanrılar tarafından ölüme mahkum edildiğini görür. Destanda Enkidu'nun ölümünü Tufan öyküsü izler. Tufan, yeryüzünün sularla dolup taşmasının öyküsüdür. Gılgamış destanında Tufan'1 tanrıça İştar ve Bel'in başlattığı anlatılır. Gılgamış, Tufan'dan kurtularak sağ kaldığını öğrendiği Utnapiştim’i bulmak üzere yola çıkar (Battero, 2015: 58-.120).
} 
biyolojik sınırları zorlaması olağan bir durum olacaktır. Ancak, bu süreçte trans-hümanistlerin yapmak istediklerini sadece robot gibi hareket eden insanlar yaratmak olarak görmek yanlıştır. Aşkın insan yetiştirmek ayrı, yapay insan yaratmak daha ayrı bir konudur.

Trans-hümanizmde amaç, yaşlılık ve ölüme ek olarak iş göremeyecek uzuvların sentetik biyoloji aracılığıyla yeniden varlığa getirilerek, biyolojik sınırların aşılma çabasıdır. Örneğin, sentetik biyoloji aracılığıyla insanın doğuştan veya sonradan kaybedilen organları yeniden vücuda getirilebilir. Hücreler üzerinde ihtiyaca göre yeni değişimler yapılabilir. Bu bağlamda, bioteknolojik alanda artık kök hücre transferine geçilmiş, genetik şifreler çözümlenmeye başlanmış, genetik materyaller üzerinde oynamayla insanın gen yapısı değiştirilme aşamasına girmiştir. Böylece hücreler sanki birer makine parçası gibi değiştirilebilme imkânına kavuşmuştur. Artık, yapay hücrelerle vücudun doğal şifresi değiştirilebilmekte ve bu anlamda, insanın genetik materyali de yapı değiştirmektedir. Gen ve kök hücre transferi ile medikal anlamda birçok rahatsızlı̆a çözüm bulunmakta ve hatta vücudun yapısı üzerine değişimlere olanak sağlanmaktadır. Örneğin, Çinli bilim insanları gen teknolojisi ile daha kaslı ve yapılı av köpekleri geliştirdiklerini belirtmişlerdir (Maxmen, 2017). Gen üzerinde yapılan değişimler, etik tartışmaları da beraberinde getirir ancak bu değişimlerin kalıtımsal hastalıklar için çözüm aracı olduğu da reddedilemez bir gerçektir.

Teknoloji, yaşam süresini uzatabilme imkânını, insanın kendi bedeni üzerinde değişimler yapma veya hiçbir değişim yapmama hakkını, isteyerek zamana direnip aynı yaşta kalma olanağını insanlığa sunmaktadır. Her ne kadar Baudrillard canlılar daha uzun süre yaşayıp, ölümden çaldıkça simgesel değerlerini yitirmektedir" (Baudrillard, 2011: 292) şeklinde bir iddia da bulunsa da teknoloji ile yaşlanmanın durdurulması, insan ömrünün uzatılması imkanı söz konusuyken, neden böyle bir olanağı kendi elimizle geri çevirelim? gibi bir soru akıllara gelmektedir. Bu kadar uzun yaşamın getireceği sıkıntılar elbette olacaktır. Ancak, bunların bize katkılarını veya zararlarını yaşamadan, onlardan pay almadan bilemeyiz.

İleri teknoloji aracılığıyla ölümsüzlügün gerçekleştirildiğini düşündüğümüzde, bu durumun getireceği sonuçları da kabullenmemiz gerekecektir. Yaşam süresinin uzatılması veya ölüme çare bulunması durumunda, dünyada nüfus artışı sorunuyla karşı karşıya kalınabilir ki bu da sosyoekonomik problemleri beraberinde getirecektir. Buradaki soru 'böyle bir durumda insanlık daha mı ileri gider yoksa daha mı geriye gider?' sorusudur. Sonsuz bir yaşam içinde hem kendileriyle hem de diğerleriyle ego savaşları içinde olan bireyler insanlı̆̆ı daha da geriye götürebilir. Burada trans-humanizm'i destekliyor olmamıza rağmen, getirdiği yeniliklerin başka sorunlara yol açabilme potansiyelinin de farkındayız. İleri teknolojiyle zihinlere farklı kodların yüklenmesi, yapay zekanın kötüye kullanılması veya organların kolayca üretilebilir hale gelmesi sorunlardan bir kısmı olarak görülebilir.

21. Yüzyılda da teknoloji bu kadar hızlı ilerlemesine rağmen ve insanlığa katkı sağlamasına rağmen ne yazık ki insanlar bunun sonuçlarını algılamakta oldukça yavaş gözükmektedirler. Elbette burada toplumun tamamının bu gelişmeleri algılaması tam anlamıla beklenemez, bu neredeyse imkansızdır. İnsanlığın evrimindeki yavaşlık ile teknolojinin hızlı gelişimi birbiriyle ters orantılıdır. İşte trans-hümanizm bu noktada araya girerek, insanın teknolojinin hızına yetişmesi için yapay zekaya fırsat tanınması gerektiğini, hatta insanın teknoloji ile üst insana doğru geliştirilmesi gerektiğini savunur. Artık trans-hümanizmde teknoloji, sadece evrimin bir parçası hatta bir üst aşaması olarak görülecektir. Bu üst aşamaya uyum sağlayamayanlar, teknolojik çağda insanlıktan kopmuş olarak nitelendirileceklerdir. 


\section{Dondurulan Yaşam}

“Ölüm artık bulunduğunu sandığımız yerde değildir. $\mathrm{O}$ artık biyolojik, psikolojik, metafizik ve hatta ölümcül bir şey de değildir. Ölüm, bu dünyanın sahip olduğu belleğin tamamen sterilize edilip, saydam bir tabut içinde dondurulmasıdır" der Baudrillard (Baudrillard, 2011: 337). Artık dondurulmuş ölüm, bir anlamda yeniden yaşama dönüşün kendisi olmuştur.

Bu bağlamda, canlı dondurma bilimi olan Kriyonik ölümü kontrol altına alma çabasındadır. Burada temel fikir, ölüleri yeniden canlandırmak için bedeni ölümden sonra korumaktır. Bu süreçte, öldükten sonra vücuttaki kan tamamen boşaltılır, yerine antifriz ve koruyucuların bulunduğu özel bir karışım aktarılır. Soğutulduğunda ise sıvı, tehlikeli kristaller oluşturmadan camsı bir hal alır ve $-196{ }^{\circ} \mathrm{C}^{\prime}$ de soğutulur. Benzer bir uygulama bu günlerde kısırlık tedavisinde kullanılan insan embriyolarını korumak için de uygulanmaktadır. Bugün bu şekilde korunmuş embriyonlardan gelişen ve büyüyen insanlar aramızda dolaşıyor olabilir. En başarılı Kriyonik çalışma, 2015 yılında Alcor'da gerçekleştirmiş olup, Burada iki hafta boyunca minik bir solucanı camlaştırmayı başardıktan sonra, belleği bozulmadan onu hayata döndürme işlemi gerçekleşmiştir. Bu da umut vaat eden bir durumdur. ${ }^{3}$ Yapay kış uykusu ${ }^{4}$ olarak da adlandırılan bu durum medikal ilaçlarla hastanın genel soğutmasıyla ortaya çıkar. Burada tedavisi olmayan herhangi bir hastalığa yakalanan bir kişinin, tedavi bulunana kadar dondurulması durumu söz konusudur (Erdemir, 2011: 663-665). Kişinin ölümünün hemen ardından hücreler henüz canlı iken dondurma işlemi gerçekleştirilmektedir.

$\mathrm{Bu}$ durum elbette gelecekte birtakım problemleri de beraberinde getirecektir. Donmuş ölülerin, dondurulmadan önceki toplumun sosyal yapisından pay alma durumu ve canlandırıldikları günkü yaşamsal değerler farklılaşacaktır. Bu nedenle de canlandırma işlemi gerçekleştiğinde, etik ve hak sorunlarıyla karşı karşıya kalınması olasıdır.

\section{Yapay Zeka}

Günümüzde ve gelecekte yapay zekâ üzerine söylenecek birçok şey bulunmaktadır. Teknoloji o kadar hızlı ilerlemektedir ki gelecek yılların yapay zekâ bakımından getireceği yenilikler inanılmaz gözükmektedir.

Yapay zekâ, bir bilgisayarın ya da bilgisayar denetimli bir makinenin yüksek zihinsel süreçlere ilişkin görevleri yerine getirme yeteneğidir (Nabiyev, 2005: 33). Yapay zekâ insan zekasıly karşılaştırıldığında, yapay zekânın daha fazla kalıcı olduğu, kolaylıkla kopyalanabilir ve geniş kitlelere ulaştırılabilir olduğu görülebilir. Oysa insan zekâsı, dışarıdan programlanmadığı için karmaşık bir yapıdadır ve kontrolü oldukça güçtür (Doğan, 2002: 61-63).

Trans-hümanizm, 1990'lı yıllarda Ray Kurzweil tarafından popülerleştirilmiştir ve Akıllı Makinelerin Çă̆g adlı eserinde kendisi, teknoloji temelinde 2045 yılı civarında yapay süper zekânın gerçekleşmesini öngörmektedir. New York'ta düzenlenen 'Küresel Gerçekler Kongresi'nde Kurzweil; teknolojik gelişmelere bağlı olarak, insanlığın ulaşmaya çalıştığı ölümsüzlük durumunun dijital dünyada gerçek olacağını iddia eder. Teorisinde, 2045'e gelindiğinde, teknolojinin insan beynini aşacağını savunur. Kurzweil, insan beyninin işleyişinin bilgisayarlara yüklenmesiyle, insanlığın dijital olarak ölümsüzlük kaynağını ortaya çıkaracağını belirtir (Özkul, 2013). Buradaki sorun; teknolojik ölümsüzlükte ortaya çıkacak olan yapay zekâ ve kişiye ait beynin bir araya gelmesiyle oluşan Ben'in birbirleriyle özdeşlik sağlayıp sağlamayacağıdır (Aktürk, 2014:

\footnotetext{
${ }^{3}$ https://cosmosmagazine.com/technology/fighting-the-common-fate-of-humans-to-better-life-and-beat-death

${ }^{4}$ Hibernasyon.
} 
29). Yapay zekâ aracılığıyla teknolojik ölümsüzlük, insanın beyninin bir makine ya da robota aktarılması sonucunda ulaşılan zihinsel ölümsüzlüktür. Bununla birlikte, beyin transferini temele alan bu teknolojik gelişmenin bir 'Ben' sorununu oluşturacağı kesin gibi gözükmektedir (Korlaelçi, 1995, 38). Ayrıca, ileri teknolojinin bedenin içine girmesi ile birlikte, varoluşumuza anlam katan, insan olmamıza neden olan duygularımızdan uzaklaşma tehlikesi kaçınılmazdır. Artık, her şey yapay zekanın egemenliğine bırakılacak ve Ben'den vazgeçme durumu söz konusu olacaktır. Teknolojik ölümsüzlük, ne yazık ki maddi olmayan Ben'i askıda bırakmış gibi gözükmektedir.

\section{Sonuç}

Nanoteknoloji, bioteknoloji, bilgi teknolojisinin birleşmesi insanın bir dizayn projesi olduğu yeni bir durumu ortaya çıkarmaktadır. İnsan genom haritasının çıkarılmasıyla, bugün üretilen yapay organların vücutta sorunsuz çalıştığına tanık olmak mümkündür. Bir sonraki aşamayı tahmin etmek hiç de güç değildir. Eğer bir insan bedeni tamamen üretilebilir ve eğer bilincin bedenden bedene aktarımı da sağlanabilirse, insan ölümsüzlüğe kolayca erişebilir. Bunun anlamı; evrimin kontrol edilebilir olduğu ve insanın kendi evrimine müdahale etme hakkının ortaya çıktığıdır.

Teknoloji çağıyla insan, teknoloji ile varlığına anlam katar ve birtakım haklar edinir. İnsan olmak doğal bir süreçtir, bunu ne makinelerle ne de gen tedavisiyle yıkabiliriz. Bununla birlikte, üst insan yetiştirmede, insanı ileriye taşıyacak olan sentetik biyolojiyi kullanmak insanlık için faydalı olacaktır. Ancak, buradaki çizgi; insanı bir nesne olarak görmek değil, bir özne olarak görüp, onun üstün insan olma talebi ile varoluşuna saygı göstermektir.

Trans-humanizm, insanın biyoteknoloji ile dansıdır. Genetik mühendisliği trans-hümanizmin tetikleyicisidir. Trans-hümanizmin ilk hedefi, ölümsüzlüğ̈̈ sağlamaktır. Trans-hümanistler, var olan ve gelişmekte olan teknoloji aracılığıyla insanlığın üst insan seviyesine ulaşabileceğini ama en önemli sorunun dünyadaki sınırlı kaynakların yetersizliğine neden olan nüfus artışı olduğunu iddia ederler. Bu nüfus artışılla birlikte insan ömrünü uzatacak genetik müdahalelerin yapılması sıkıntıları da beraberinde getirecektir. Bununla birlikte, şimdiden dünya nüfusunun had safhaya ulaşması, başka evrenlerde yaşam sağlanabilir mi araştırmalarının ortaya çıkmasına da neden olmuştur. İkinci hedef ise insan bilincini en üst düzeye çıkararak yapay bir zekâ kurulumu sağlamaktır. Trans-hümanizm ile birlikte yapay zekâ teknolojisi egemenliğini evrende kurmaya başlar. Bilincin tamamen dijital bir alana aktarılmasındaki neden, insanın kendi bedeninin bilincin gerçek kapasitesini sergilemesine izin vermediği düşüncesidir. Ancak yapay zekâ üretilmesi, birtakım sorunları da beraberinde getirir. Yapay zekanın uygulanması, var olan sınıf ayrılıklarının daha da farklı şekiller alarak derinleşmesine neden olabilir.

Ölümsüzlük ve yapay zekâ temelindeki Ben aktarımı, evrime karşı bir müdahale olarak tanımlanabilir. Özellikle, genetiği yapay olarak değiştirilen organizmaların, gelecekte hem varoluşsal hem de siyasal bağlamda ne gibi sorunlar yaratacağı bilinmemektedir. Bu durum da her ne kadar trans-hümanizm insanlık için olumlu adımlar atsa da yaşam biçiminin değişmesi ve bunun da bazı yaşamsal belirsizlikleri beraberinde getireceği kabullenilmesi gereken bir gerçektir. 


\section{Kaynakça}

Abbagnano, N. (1992). Hümanizm. (N. Kale Çev.). Ankara Üniversitesi Dergileri. 25 (2): 763-770.

Aksakal, O. (16 Kasım 2012). Transhümanizme Griş-1. Erişim Tarihi: 12.10.2017. http://heran.org/2012/11/transhumanizme-giris-1/\#sthash.0FPNYFEI.dpuf, 1992.

Aktürk, E. (2014). Eskatolojik Açıdan Kişisel Özdeşlik Sorunu. Ankara: Araştırma Yayınları,

Baudrillard, J., (2011). Simgesel Değiş Tokuş ve Ölüm, Çev: O. Adanır, Boğaziçi Üniversitesi Yayınları, İstanbul.

Bilgen, H. (, 2014). Biyoteknoloji ve İnsan Hakları: Transhümanizm Hukuk Alanına Nasıl Girdi?.

Erişim tarihi: 22.10.2017 http://www. medikalakademi.com.tr/biyoteknoloji-veinsan-haklari-transhuemanizm-hukuk-alanina-nasil-girdi.

Battero, J. (2015). Gılgamış Destanı. (Çev: O. Suda), Yapı Kredi Yayınları, İstanbul.

Bostrom, N. (, 2003)., The Transhumanist FAQ, Published by the World Transhumanist Association.

Doğan, A. (2002). Yapay Zekâ. Kariyer Yayınları, İstanbul.

Erdemir, A. D. ( 2011). Tipta ve Etikte Deontoloji. Nobel Tıp Kitapevleri, İstanbul.

ones, R. (2016). Against Transhumanism The delusion of technological transcendence. Erişim tarihi: 22.10.2017.

http://www.softmachines.org/wordpress/wpcontent/uploads/2016/04/Against Transhum anism 1.0 small.pdf,

Korlaelçi, M. (1995.). İnsan Benliği. Felsefe Dünyası Dergisi, 15, p. 30-41,

Maxmen A. (03 November 2017). Three technologies that changed genetics. Nature 528, S2-S3. doi:10.1038/528S2a.

Nabiyev, Y. V. (2005). Yapay Zekâ. Seçkin Yayınları Ankara:.

Nietzsche, F. (2011). Böyle Buyurdu Zerdüşt, Panama Yayınları,

Özkul, İ. S. (31 Mayıs 2013). 2045 İnisiyatifinin ölümsüzlük projesi. Erişim tarihi: 20.11.2017, http://her-an.org/2013/05/2045-inisyatifinin-olumsuzluk

projesi/\#sthash.Ep8aiuvD.dpuf. $\quad$ https://cosmosmagazine.com/technology/fighting-thecommon-fate-of-humans-to-better-life-and-beat-death

More, M. (2004). Extropian Principles 3.0. Erişim tarihi: 18.01.2018. http://www.maxmore.com/extprn3.htm,

Bentham, J. (1996), An Introduction to the Principles of Morals and Legislation (1789). (ed.: J. H. Burns and H. L. A. Hart), Clarendon Press, Oxford.

Hansell, G. R. and Grassie, W. ( 2010). Transhumanism and Its Critics, Metanexus. 
